\title{
HOMENAGEM A UM GRANDE BRASILEIRO - EDGARD DE CERQUEIRA FALCÃO (1904-1987)
}

O Brasil acaba de perder um de seus mais operosos escritores, cuja vida foi toda ela dedicada ao trabalho, devendo seu nome ser apontado ao respeito e à admiração da coletividade. A base de sua vitoriosa carreira estava na diligência extremada e na imperativa continuidade de realização. O legado que este brasileiro ilustre nos deixa é verdadeiramente impressionante. Lutando dia e noite, vencendo mil barreiras, realizou obra notável, imensa e variadíssima, milhares de páginas que enriquecem a bibliografia nacional. Poucos fizeram tanto pela cultura de nossa terra, como Edgard de Cerqueira Falcão. Seus livros - espólio bibliografíco notável, estão hoje sob minha guarda. O berço deu-lhe a pureza dos sentimentos, a vida o entendimento irrestrito das vaidades e aspirações alheias e a medicina cientifica a objetividade, a tolerância na aferição dos atos humanos e a medida na exteriorização do pensamento. Consagrou a vida inteira a seus livros, cujas insônias o impediam de dormir. Realmente, eu não sei dizer como Edgard de Cerqueira Falcão possuia tempo para realizar tanta coisa útil ao nosso meio, numa obra de brasilidade verdadeiramente espantosa. $O$ desinteresse pecuniário, a dignidade profissional, o devotamento a seus mestres, de tudo isto deixou exemplo, assentamento nesses principios o fulcro de uma atuação médica, social e humanitária de ressonância imorredoura na lembrança dos brasileiros. Ele honrou a nossa profissão como um modelo imaculado de todas as virtudes médicas. Nasceu Edgard de Cerqueira Falcão na cidade de Salvador, a 10 de abril de 1904, filho do Bacharel Theophilo Borges Falcão e Maria das Dores de Cerqueira Falcão. Fez os cursos primário e secundário na própria terra natal, matriculando-se em 1920, muito jovem, na Faculdade de Medicina da Bahia, de onde saiu aluno laureado em 1925, fazendo jus à colocação de seu retrato no Panteon da Escola.

Ainda estudante, colaborou intensamente com o Dr. Genésio Pacheco nas pesquisas sobre a epidemia da febre tifóide na Cidade de Salvador, ano de 1924, sendo seu gesto altruistico devidamente reconhecido pelo então Governador do Estado, Dr. Góes Calmon, de quem recebeu, ao colar o grau de médico, uma carta laudatória e rico presente.

Uma vez diplomado, transferiu-se para a cidade de Santos, São Paulo, onde se fixou, definitivamente, e recebeu, em 1963, a Medalha do Mérito Cultural Cidade de Santos, pela primeira e única vez outorgada, até então.

No ano seguinte, 1964, foi agraciado com o titulo de Cidadão Santista.

É dificil resumir a trajetória de Edgard Falcão nos setores da ciência, da história, da biografia e da arte, uma vez que 52 livros de sua autoria já foram publicados até o momento. Nessa extensa bibliografia, impossível de mencionar na integra, a Bahia foi alvo de especial destaque, sendo dignos de referência Rellquias da Bahia, Roteiro de Paulo Afonso, Fortes Coloniais da Cidade do Salvador, Encantos Tradicionais da Bahia, além de outros de cunho particularmente histórico. Merece realce especial a série Brasiliensia Documenta, composta de 10 obras de indiscutivel valor.

Os grandes vultos da ciência médica, mercê do devotamento às suas memórias, reviveram através do $\mathrm{Dr}$.
Edgard Falcão, que não poupou esforços para tornar conhecidas a vida e a obra dos Drs. Manuel Augusto Pirajá da Silva e Oscar Freire, seus ilustres conterrâneos, Gaspar Vianna, Rocha Lima e Oswaldo Cruz, luminares da medicina no Brasil.

Não foram esquecidos outros brasileiros de renome internacional, entre os quais José Bonifácio de Andrada e Silva, o Patriarca da Independência, Alexandre Rodrigues Ferreira, insigne naturalista baiano e Santos Dumont, o Pai da Aviação.

Estes e outros livros publicados, somados à obra cientifica de Edgard Falcão, Ihe proporcionaram merecidas honrarias, destacando-se o prêmio Medalha de Ouro Sociedade Paulista de História da Medicina, recebido em 1959, pelo conjunto de trabalhos intitulado Pirajá da Silva, sua vida e sua obra, o prêmio Arnaldo Vieira de Carvalho, unferido pelo trabalho Últimas Achegas, em 1961; novamente o prêmio Medalha de Ouro Sociedade Paulista de História da Medicina, outorgado pelo trabalho Henrique da Rocha Lima e a descoberta da Rickettsia prowazeki. Mas, a estas informaçōes apontadas, devemos acrescentar, pela sua importância, Notícia do Brasil, de Gabriel Soares de Souza, na 8 a edição.

Reconhecendo o valor de Edgard Falcão, o Pen Clube de São Paulo conferiu-lhe, em 1965, uma Medalha de Mérito Excepcional, pelo lançamento das Obras Científicas, Politicas e Sociais de José Bonifácio.

Não admira, pois, que além das mencionadas distinções acima referidas, recebesse também as medalhas comemorativas - Machado de Assis, Imperatriz Leopoldina, Carlos Chagas, Marechal Rondon, Nina Rodrigues, Vital Brazil e outras.

Credenciado pelo Itamarati, Edgard Falcão representou oficialmente o Brasil no IV Congresso Internacional de História da América, realizado em Buenos Aires, em 1966. Em 1967, recebeu a Ordem do Mérito Naval, no grau de Cavaleiro, em atenção às publicaçōes sobre José Bonifácio, fundador da Marinha de Guerra do Brasil. Ultrapassando as fronteiras da Pátria, Edgard Falcão foi agraciado em 1969, com a Cruz de 1a Classe da Ordem do Mérito da República Federal da Alemanha.

Como não bastassem tantas honrarias, por Decreto assinado pelo Presidente Castello Branco, em 11 de janeiro de 1967 , nosso conterrâneo recebeu, no grau de Comendador, a Ordem do Mérito Médico e, no de Cavaleiro, a Ordem do Mérito Militar. Foi agraciado em 1971, com a Ordem do Mérito Aeronáutico no grau de Oficial; e, neste mesmo ano, o Instituto Histórico e Geográfico de São Paulo conferiu-lhe as Medalhas Alexandre de Gusmão e Manuel da Nóbrega.

Ressaltamos de início as publicações de referência à Bahia, entre as quais se destaca esse monumento que é Relíquias da Bahia. Sua visão de esteta, fixou através de fotografias impecáveis o que possuimos de mais belo em matéria de arte. Suas vistas se voltaram também para Minas Gerais, que ele imortalizou através das Reliquias da Terra do Ouro, provando que um cientista pode ser, ao mesmo tempo, um historiador, um excelente biógrafo, um dissemi- 
nador da cultura em quaisquer de suas modalidades, conforme comprovamos nestas ligeiras notas biográficas.

Esses dados biográficos nós os devemos a Marieta Alves, em seu livro "Intelectuais e Escritores Baianos".

Desejo destacar, nesta homenagem ao eminente historiador brasileiro, a admiração e respeito que ele tinha para com seu mestre e amigo Prof. Pirajá da Silva, de saudosa memória.

O eminente médico, pesquisador e escritor faleceu em Santos, a 8 de fevereiro. Foi ele, no dizer do Prof. Bardi, um dos últimos artesãos de revisão da histórica, raça que vai aos poucos desaparecendo. Passa depressa o tempo dos vivos.

\begin{abstract}
Eterno, porém, é o dos mortos, na relembrança da nobreza com que viveram. Falcão será para sempre relembrado, tempo a fora, porque sua vida foi lição de beleza, de inteligência e de altruismo. Bendita, pois, a memória do grande mestre da história da medicina brasileira. Amigo e admirador do eminente médico baiano, presto-lhe minha homenagem ao vê-lo partir para sempre. Ele viverá em nosso pensamento e em nossa reverência. Vira-se para sempre a última página de uma das mais belas e fecundas carreiras de nossa historiografia médica, a qual, mais do que a própria classe, dignificou a espécie humana. Nós, seus amigos e colegas, haveremos sempre de celebrar-lhe a memória com os hinos de nosso afeto e de nossa saudade.
\end{abstract}

\section{CONGRESSO DA SOCIEDADE LATINO-AMERICANA DE PATOLOGIA (SLAP) $\Theta$ XVII CONGRESSO DA SOCIEDADE BRASILEIRA DE PATOLOGIA (SBP)}

Entre os dias 20 e 25 de setembro vindouro os patologistas brasileiros e seus colegas dos demais países latino-americanos vão se reunir no Centro de Convenções em Salvador para debater temas de grande interesse durante o XVI Congresso Latinoamericano e o XVII Congresso Brasileiro de Patologia, em sessões conjuntas. Serão analisados os progressos recentes no campo da inflamação, tỉbrose, transplantes de órgãos, no emprego de novas técnicas para o diagnóstico de doenças importantes, como o câncer nas crianças, os tumores do sistema nervoso, bem como uma avaliação do comportamento atual de velhas doenças, como a lepra e a malária, e de novas doenças, como a AIDS.

Maiores informações poderão ser obtidas no seguinte endereço: Secretaria Executiva - EVENTUS - Operadora de Congressos Ltda. Rua 8 de Dezembro 547 - Graça - 40130 Salvador, Bahia, Brasil (telefones: 071-247.4978/8119). 